\title{
The Good, the Bad and the Ugly of Teaching Practice at an Open Distance Learning Institution: A Case Study
}

\author{
Anne-Mari Dicker \\ Associate Professor, AJH vd Walt 7-43, University of South Africa, 0124294630 \\ dickeam@unisa.ac.za \\ Alena van Schalkwyk \\ Senior Lecturer, AJH vd Walt 6-31, University of South Africa, 0124294451 \\ Vschaa1@unisa.ac.za
}

Doi:10.5901/mjss.2014.v5n27p610

\section{Abstract}

To meet the demands in an era of career-oriented education, the training of future teachers through Open Distance Learning must be scrutinised to see if it meets these demands. Especially the teaching practice aspect of training teachers through Open Distance Learning offers its own unique challenges to ensure that student teachers gain the best possible teaching experiences during this period. This is due to the Open Distance Learning environment where there is a distance in space and time between the lecturers responsible for the Teaching Practice modules and the student teachers doing their practical teaching at different schools. Teaching Practice modules are grounded in situated and experiential learning experiences. The theoretical frameworks for this study are experiential learning and situated learning theory. The data were collected from student teachers busy with their final year BEd (Intermediate Phase and Senior Phase) who had already completed their five weeks teaching practice for each of the four years. By taking note of the answers supplied by these student teachers, the lecturers endeavour to better understand the context of teaching practice within an Open Distance Learning context/environment. The data presented the following themes: students' experiences, the mentoring process and empowerment, and finally the feasibility of conducting teaching practice at a distance. This also assists the lecturers in attending to any problems or difficulties that the student teachers identified and enables them to concentrate and build upon the positive aspects regarding their Teaching Practice modules. The findings are important as a basis for further recommendations to improve student teachers' successes during their teaching practice period within the framework of an Open Distance Learning environment.

Keywords: experiential learning; Open Distance Learning (ODL); situated learning; student teachers; teaching practice (TP)

\section{Introduction}

The Department of Education in South Africa expects student teachers to complete Teaching Practice (TP) modules as part of their experiential learning for the BEd (Intermediate Phase and Senior Phase) degree. The degree includes four TP modules, each equal to 12 credits based on five weeks' practical teaching experience at a school. The student teachers must acquire practical or applied work-integrated learning (WIL) through first-hand teaching experience in a school setting. Another 36 knowledge-based modules make up the rest of the 40 modules the student teachers must successfully complete for their BEd degree. At an Open Distance Learning (ODL) institution student teachers are given a knowledge base in their theoretical course work as well as applied practical learning through first-hand teaching experience during the yearly five weeks in a school setting (Shulman 2004).

ODL provides access to learning even when the source of information and the student teachers as learners are separated from their lecturers by either time or distance, or both. This has both advantages and disadvantages for the students enrolled at an ODL institution. Some of the advantages are that it enables students who, owing to various reasons, are unable to attend traditional residential universities to still have access to a good education. It is flexible, which lessens the effects of time constraints that might be imposing on the student's time. Furthermore, lifelong learning thus becomes the trend of the information age and millennial students. According to Kolb $(1984,2013)$, the challenge of lifelong learning is above all a challenge of integrative development. ODL allows students (as learners) to keep abreast of developments in their field of study as well as to change their careers at any given time (Menlo \& Poppleton 1990). 
When we use the word "experience" in TP and experiential learning, we are usually referring to a practicum rather than the complex notion of experience per se (Jarvis 2009). To empower the student teachers via the TP component at an ODL institution, the practical applications of the teaching profession should enable them to reap the maximum benefits from their teaching-practice periods at schools. Therefore there should be cooperation between the different role players in the education and training of student teachers, namely the lecturers of the ODL institutions, the schools that accept student teachers from ODL institutions and the student teachers as well as their mentor teachers. These cooperative "partnership" models of the key stakeholders to support the initial teacher education are of the utmost importance for the support of teacher training at an ODL institution (Maeroff 1988).

On the other hand, disadvantages could include problems such as the lack of lecturers' support, domestic distractions, financial worries and lack of resources/technologies. Over the past few years it became evident that within the context of an ODL environment, maintaining proper quality over TP teaching-learning experiences presents its own unique problems (Shulman 2004). A challenge to overcome is that as the student teachers and the lecturers of the ODL institution are not physically together in a traditional classroom setting, the student teachers are separated from their lecturers in space and time. Furthermore, teaching, especially through ODL, tends to be content centred, rigid and lecturer driven, providing student teachers with secondary content experiences which are nearly always purely cognitive (Jarvis 2009:7-8). Although modern media such as the internet and technologies, for example e-learning and videoconferencing, help to cross over the distance between time and space, the lecturers need to resort to challenging teaching activities to bring the best possible learning content and practical teaching experiences to their student teachers (Juwah 2010; Butcher, Latchem, Manoyo \& Levey 2011; Jedege 2009; Louw \& Steyn 2012). The only way to break what is called the "space-time barriers" of ODL education would be to separate teaching and learning. This involves planning teaching and learning as separate activities so that educational opportunities may be provided in any place where there are student teachers, whether or not there are lecturers at the same place at the same time (Çakiroğlu 2014).

It is important for lecturers involved with TP components at an ODL institution to establish from their investigations whether there are strengths (the good) and weaknesses (the bad) in their presentations, assumptions and assessments regarding student teachers' WIL experiences as part of their TP modules. A brief literature background to determine the good or the bad aspects of TP experiences at an ODL institution in conjunction with experiential learning will be given next.

\section{Literature Review}

The ODL mode of learning, TP and mentoring are concepts that need to be explained and they will be addressed from existing literature.

Jedege (2009) suggests that the use of ODL as an alternative mode of educating student teachers has more claim to community development than the conventional mode of learning, namely face-to-face teaching. As it involves and allows everybody and anybody to seek knowledge at their own convenience, the fundamentals of student-centred ODL enable easy interaction with the immediate social school community. The knowledge gained by student teachers as learners is directly integrated into the community and this also happens faster than through the conventional residential mode. Additional benefits of ODL for student teachers are

- flexible access and equity for comprehensive national development

- alleviation of capacity constraints such as economics, human resources and rural development

- lifelong education and WIL in order to build a learning and knowledge-based society

- education for all, especially to reduce or totally eliminate illiteracy and poverty and

- capacity building for human resource development, especially in areas such as vocational and technical education, science and technology to mention but a few (Jedege 2009; Butcher et al 2011; ODL Communiqué 2010).

Field experience is an important part of teachers' education, and even more so in an ODL setting. It provides time for professional growth and offers prospective teachers' opportunities to explore concepts and practise techniques learnt in education courses (Lasley \& Applegate 1985). Teaching practice is the preparation of student teachers for the teaching activities that they as professionals will have to do in the workplace, namely the school. TP enables student teachers to become more professional and to improve their teaching performances as well as be more knowledgeable about their subjects. Empowerment depends very much on lifting the status of teachers. Teachers feel more empowered when they are part of a group with a common purpose than when they teach on their own. Teachers are separated in their classroom and normally have little time to share and compare ideas with colleagues. Professional growth is bound to be 
impaired in a setting where teachers do not see their colleagues practise their profession and hardly ever teach one another new techniques (Maeroff 1988). If they can come together to work on a project with other teachers who share their dedication and conscientiousness, it could lead to the sharing of ideas for empowerment. Shulman (2004:12) states that "teaching alone, learning together" would be the way to go about giving the student teachers the maximum exposure to teaching activities during their field experience.

This places the onus on ODL to adapt to the needs of its immediate community. For the educational opportunities provided through ODL to be relevant to the current needs of the community, the ways of putting together or directing student teachers (the learners) to the fountain of information will need rethinking (Jedege 2009). Integrative learning experiences take on a new meaning and vitality when they are directly connected with the integrative challenges of adult life. The teaching and learning of adult learners at ODL institutions are based on andragogy. Every ODL institution is involved with the education and training of adult learners. According to Taggart and Wilson (1998), andragogy, the teaching of adults, is based on several assumptions about student teachers as adult learners:

- The need to know is strong in adult learners. Benefits, consequences and risks must be ascertained prior to involvement in the learning situation. Shulman (2004) proposes that teaching requires various kinds of knowledge, including knowledge of rules (research), knowledge of particular cases (theory) and knowledge of how to apply the rules to specific teaching activities (practice) (Maeroff 1988; Shulman 2004; Taggart \& Wilson 1998). The opportunity to learn from practical teaching experiences would be realised by gaining an understanding of and practising professional judgement as well as making decisions during practical teaching periods at schools. Only then could professional knowledge become part of student teachers' individual capacity to teach in their life world or immediate social (school) community.

- Readiness to learn is inherent in adult learners. As a team effort of collaboration between the ODL lecturers, the mentor teacher and the student teacher, the student teacher needs to be guided to be able to think critically and creatively, solve problems, make informed decisions and observe (Gokhale 1995). Often student teachers regard the mentor teacher as a source of ideas for planning lessons or gaining administrative information rather than someone who clarifies and explains what she/he does. They ask the mentor "how to" rather than "why". If there is no reflection, student teachers do not learn as much from the practical experience and from what they observe, because they lack the opportunity to think about, analyse and reflect on it. Reflection would allow them to benefit from experience as it necessitates doubt and perplexity, conjectures, careful thought, clarification and hypothesis testing (Shulman 2004). The teaching activities for student teachers must be clearly set out from the start and even more so in an ODL context.

- Experiential learning built on adult student teachers' past experiences is essential. Group discussions, stimulations and problem-solving activities emphasising peer collaboration have proven effective with adult learners. Student teachers are begging for stimulating educational experiences and to acquire knowledge. The fact that student teachers can learn from TP is supported by the involvement of experienced teachers (mentors) in schools who are mentoring the student teachers. This could free teachers from ways that are stifling their teaching practices and empower them to act differently (Maeroff 1988). The theoretical course work given to the student teachers in their academic modules support practical teaching application in their teaching modules. For assessment purposes it is expected that student teachers complete several workbooks containing lesson plans during their five weeks at a school.

- The self-concept and intellectual responsibility of adult learners lend credence to self-directed learning situations. To benefit most from the TP experience, the student teacher needs guidance in interpreting and making the connection between her/his teaching activities and their consequences. When student teachers become partners in the situated learning process, they gain a better sense of themselves as teachers. Student teachers develop the teaching tools to become more effective learners as well as teachers by being active participants in the learning situation. By participating, student teachers will understand the criteria for good work. The use of direct observation, such as the objectives methods of behavioural feedback, has been shown to be instrumental in improving the instructional process (Clark, Steele, Niemiec \& Walberg 1992). During teaching practice, student teachers learn from two modes of experiences. The first mode of learning is the practical experience by participating or the direct encounter in an actual teaching experience and the second mode of learning is learning by watching or observation of mentor teachers' teaching activities (Evans 1986). Student teachers' observations and reflections can also provide valuable feedback for refining the instructional methods and activities of the lecturers at an ODL institution.

- The benefits of observation during the field teaching experience would be derived from understanding 
educational phenomena. Observing the contrasting teaching styles will alert student teachers to what they should and should not do while teaching. Student teachers tend to teach as they had been taught, which means modelling their teaching activities on something they learnt a long time ago. Those who complete their degree and go out to teach after a few years say that the courses they took in the method of teaching were largely a waste of time (Maeroff 1988). The direct encounter with the mentor teacher, the learners and classroom phenomena will bring about some understanding of learners and classrooms that student teachers could not learn in an academic or any other context. Student teachers develop skills and new perspectives on teaching activities. Teacher education is a public matter that engages every member or consumer of society with its indirect effect on the individual student teacher's quality of life, as well as its impact on the development of the economy and society (Eacute \& Esteve 2000; Gokhale 1995; Zeichner 1986).

All these factors play a very important part in the successful completion of student teachers' TP component. Everyday teaching knowledge in a school setting is not the same as academic knowledge (context independent in the learning material) and is also structured differently. In a school, the student teacher could recontextualise everyday social teaching activities to the academic environment. The social presence is useful in improving thorny issues such as retention and success in ODL education (Butcher et al 2011; Subotzky \& Prinsloo 2011).

The TP modules form part of a series of learning situations for student teachers in which they are confronted with or can practise real-life teaching activities and classroom management under the supervision and mentoring of experienced teachers. To find out how the ODL TP modules support these learning experiences, this research will be based on the theoretical concepts set out below.

\section{Theoretical Concepts}

Any research is based on proven theory. For this study, the theories of situated learning and experiential learning form the theoretical framework.

Lave and Wenger $(1991 ; 2011)$ formulated their situated learning theory based on the fact that learning takes place as a function of the context, culture and activity in which it occurs. The context of learning is situated in the social engagements of the participators, namely the expert master or mentor teacher and the novice apprentice or student teacher, where identity, membership and interpersonal relations are significant within a school setting. The individual student teacher develops and identifies within the context of the community of practice the teaching practices appropriate to that community.

Wenger $(1998 ; 2000)$ identifies the following three elements that define his community of practice:

- There is a mutual engagement of participants in action as student teachers' roles are those of apprentice learners within a school setting (Sykes, Bird \& Kennedy 2010). This could be defined as "undertaking or engaging fully in a task, job or profession in order to learn".

- There is also a negotiation of a joint enterprise as the student teachers do their practical teaching under the guidance of lecturers or their mentor teachers (as masters). In situated learning the role of the master as a mentor has undergone drastic changes through the years. Currently, mentorship guidance is seen as establishing and building a relationship that would benefit the mentor teacher as well as the mentee student teacher (Booysen 2013).

- There is a development of a shared repertoire that involves novice student teachers as legitimate peripheral participants in the practices of their communities during their TP experiences at schools. The mentor teacher and student teacher collaborate in a social engagement and teach together in a school as a team (Gokhale 1995). Learning is most effective and efficient when student teachers are engaged in reflecting upon their teaching actions and problem solving, thus learning by doing within an authentic/experiential learning context (Anderson, Reder \& Simon 1996; Naidu 2010).

Kolb $(1984,2013)$ stated that human beings are a "teaching species" as well as a "learning species". It is important for schools to have teaching as the most important activity and to value teachers as professionals who can create a social environment of constant learning for themselves as well as for their learners, as teachers are the basis/foundation of schooling (Maeroff 1988). Therefore the TP modules can also be supported by the experiential learning theory as set out by Kolb $(1984,2013)$. To facilitate personal growth, each student teacher must be exposed to as many real-life teaching experiences as possible, as all real-life experiences are intrinsically interwoven (Schlebusch 2009). Individual teachinglearning styles are shaped by the structure of social knowledge and through individual creative acts. This includes the individual development of student teacher participants at ODL institutions in all three developmental stages of experiential learning, namely acquisition, specialisation and integration (Kolb 1984; Unisa 2012). 
- Acquisition refers to the preparation of individual student teachers in basic teaching skills so that they can access and utilise the tools of social knowledge. TP experiences lead to student teachers acquiring teaching skills through personal experience, reflective observation and collaboration with mentor teachers. Student teachers' concrete TP experiences will lead to the practical acquiring of techniques. This is marked by the gradual emergence of external stimuli in internalised structures that allow the student teacher to gain a sense of self (Kolb 1984; Gokhale 1995).

- Specialisation implies the selection and socialisation of student teachers into specialised areas of knowledge that suit their talents and meet societal needs. Student teachers also tend to select themselves into environments that are consistent with their personal characteristics. The choices a student teacher makes in this process tend to have an accommodating, self-fulfilling quality that promotes specialisation. There will be dynamic interaction between internal personality characteristics and external environmental and social forces (Kolb 1984, 2013). The primary mode of relating to the world is interaction and collaboration, and student teachers contribute to and partake with the mentor teacher in teaching activities.

- Integration entails the development of the unique capacities of the whole person towards creativity, wisdom and integrity. The transition between stages 2 and 3 of development is inter alia marked by the individual student teacher's personal, existential confrontation of the conflict between social demands and personal fulfilment needs (Kolb 1984, 2013). The reflective learner, rather than being influenced, now sees opportunities to influence and participate in active teaching experimentation rather than merely observing and accepting experiences as they happen (Platsidon \& Metallidou 2009; Kolb 1984, 2013; Gokhale 1995). These challenges to conceptualise abstract knowledge shape the student teacher's own teaching experience.

Since all social knowledge is learnt, it is reasonable to suggest that there is some morphism between the structure of social knowledge and the structure of the learning process (Kolb 1984). From the perspective of situated and experiential learning theories, ODL institutions are the curators of social knowledge (Kolb 1984; Wenger 2000). One of the main responsibilities of this curatorship is the creation of conditions whereby social knowledge is made accessible to individual student teachers for their development during teaching practice. Higher education is increasingly called upon to deliver the specialised knowledge, skills and attitudes needed for student teachers to find their niche as well. ODL institutions, in turn, become increasingly dependent on these social niches for their own survival and lend further support to student teachers completing their TP in the social communities, namely schools (Bliue, Ellis, Goodyear \& Hendres 2011).

\section{Research Design}

The researchers used an exploratory qualitative research design in order to gather rich in-depth data from the fourth-year BEd (Intermediate Phase and Senior Phase) student teacher participants who had completed their last five weeks of teaching practice at schools. The participants were all studying within an ODL context and were compelled to conduct four TP periods consisting of five weeks' school-based practice between February and September each year. The aim was to find out from the student teachers what the good (positive) and the bad (negative) teaching experiences were that they encountered throughout their four years of studying and conducting TP periods at schools. This method provided participants an opportunity to reflect on the good and bad experiences, attitudes and gains of the ODL TP modules of their BEd studies.

Open-ended questionnaires were mailed to all the fourth-year student teachers. In this case study, the process is more important than the outcome (Henning 2004). Purposive sampling was used and 32 participants' completed questionnaires with narratives were selected. Saturation of data was reached and therefore only 32 respondents were included in the data collection. The questionnaire consisted of a number of activities in which student teachers had to provide biographical information and were probed to write down positive and negative aspects of the teaching practice, give suggestions regarding mentor teachers, the mentoring process, empowerment, general administrative aspects (e.g. placement, communication via online, videoconferencing, fax, announcements, e-mail) and assessment methods. Student teachers' narratives were captured in the space provided on the questionnaire.

The following biographical information relates to the selected student teacher participants: 


\begin{tabular}{|l|c|c|c|l|c|c|c|}
\hline \multicolumn{9}{|c|}{ Biographical Data } \\
\hline Gender & Age group & Position in School & \multicolumn{2}{c|}{ SCHOOL } \\
\hline Male & 7 & $<30$ & 18 & Learnership & 3 & PRIMARY & 30 \\
\hline Female & 25 & $31-39$ & 11 & Permanent & 13 & SECONDARY & 2 \\
\hline & & $40-49$ & 1 & Part-Time & 7 & & \\
\hline & & $>50$ & 2 & Other & 9 & & \\
\hline
\end{tabular}

There is a fair distribution of male and female students keeping in mind that in the Intermediate Phase there is usually more female than male teachers. From the age distribution, it is clear that student teachers range from young adults in their twenties to mature adults. The students represent different positions at school, for example learnerships (either permanent or part-time at the schools), and various other positions not in schools. The sampling size was determined on the basis of theoretical saturation and the objectives of the research. A limitation is that the sample of student teachers is not a complete representation of all the BEd students, but for the purpose of this study the sample still provides the researchers with a good set of data to make sense of and describe the quality of the ODL TP modules.

All necessary ethical measures were adhered to. For example, the participants' anonymity was guaranteed. A covering letter was included to give clear information and instructions to all the participants. The trustworthiness of the research and data presentation is based on the principle of multiple researchers participating in the data analysis process. This ensures triangulation in the analysis and interpretation of data. From the data several themes and subthemes emerged. These will be discussed next under the findings.

\section{Data Analysis and Findings}

In the questionnaire broad probing questions were asked. From the completed questionnaires the following main themes and sub-themes were identified. After an analysis and interpretation of the qualitative data, the research findings are now presented as three themes. These themes identify the good (positive) and the bad (negative) comments of the student teacher participants and will be discussed next.

\subsection{Theme 1: Experiential learning through mutual active engagement in teaching activities by student teachers}

Student teachers were asked to comment on the good as well as the bad experiences that they experienced during their stay at the schools.

\subsubsection{Positive aspects}

According to Taggart and Wilson (1998:8), experiential learning occurs most effectively through mutual social engagement in collaboration and problem solving leading to the acquirement of teaching skills. Student teachers commented that TP time spent at schools as communities of practice "helps a lot to acquire knowledge and skills in the field of teaching profession". They learnt much by being "exposed to many professionals" and "get[ting] guidance from other senior teachers". It was mentioned that the support provided by the entire staff and principal of the school made it a very positive experience as the student teacher was part of staff teaching activities and other social development. "It contributed to my self-confidence." "The experience with the learners makes it worthwhile." Cognitive apprenticeship comprises the development of cognitive skills with the guidance of an expert (the mentor teacher), much like the handson teaching experience under the close tutelage of an experienced practitioner (Naidu 2010). There is however, a need for ODL lecturers to direct this teaching experience for the student teacher with mentor teacher collaboration during active TP engagement with the learning content.

The structure of the TP modules gives student teachers the opportunity to explore all the different subjects and they "enjoyed all the teaching practice modules". Student teachers experience first-hand how it is to teach and they "gain a lot of experience, good teaching methods and problem solving" skills. Direct participation in an actual classroom experience is the best way to the acquisition of basic teaching skills through experiential learning.

Teachers frequently are the victims of the inadequacy of their own education, because it does not equip them to bring intellectual authority into the subject matter they teach. This has brought the whole approach to teacher education as well as in-service training into question (Maeroff 1988). Internalising teaching skills is a dynamic approach to learning where the purpose is to foster the development of individual student teachers to become active, critical and productive societal members within school communities (Jarvis 2009). Teaching practice, embedded in situated learning, is therefore 
a necessary mutual engagement for student teachers to learn and practise their teaching skills under the guidance of mentor teachers.

\subsubsection{Negative aspects}

Student teachers commented on the following negative aspects regarding their TP experience. Children's behaviour and the school's attitude were a concern. These contributed to the student teachers' struggle with discipline. Sometimes mentor teachers would not involve student teachers in classroom activities, which may lead to boredom. The opposite was also reported where mentor teachers would overburden student teachers with marking and substitute teaching to the extent that they could not find enough time for their own TP assignments.

An administrative issue mentioned pertains to the supervisor (appointed by the TP office) who did not stick to appointments or changed them at the last minute, which is a bad reflection on Unisa.

\subsection{Theme 2: Specialisation and empowerment through mentoring during a joint teaching enterprise of student teachers and mentor teachers}

To establish whether mentor teachers take responsibility for student teachers placed at schools, student teachers had to write about their experiences with their mentor teachers.

\subsubsection{Positive aspects}

No account of human learning could be considered complete without an examination of culturally accumulated knowledge, its nature and organisation, and the process whereby individual learners contribute to and partake of that knowledge as part of a community of practice. From the same perspectives, the social situated learning theorists claim that the personal construction of knowledge always occurs in a social context, since learning activities are socially and contextually bound as a joint enterprise. Learning is an active process of constructing meaning and transforming understanding during the interaction with the work environment (Kolb 1984, 2013). Student teachers as learners should play an active role in constructing knowledge, as learning is collaborative and they learn from the interaction with their mentor teachers (as the masters) and their own peers. There should be a continuous reciprocal interaction to ensure that this learning process is a productive and successful joint enterprise that leads to empowerment and subject specialisation.

Students reported that the mentor teachers enhanced their self-confidence, because the teacher "believed in me, involved me with other staff". "I am not a public speaker ... I had to come in front of a class of more than 45 learners for the first time, it was daunting ... it helped me to grow and gain self-confidence." "The mentor teacher set an excellent example for me to follow. She is punctual, well prepared and dedicated." The "mentor teacher discussed every lesson before it was presented", thus providing valuable input and learning.

The good and bad comments assist the student teacher to reflect and work on the lesson plans to improve them. "Also different ways of disciplining noisy and unruly students helped in maintaining a disciplined and manageable class." By providing student teachers with these joint teaching-learning experiences, they have an opportunity to share teaching skills, understand themselves better and be empowered by their restored confidence to become legitimate participants in this joint enterprise.

\subsubsection{Negative aspects}

Schön (in Taggart \& Wilson 1998) describes a problematic situation as the initial step of reflection in action. A negative aspect in the school is that mentor teachers are sometimes impatient and do not want to accommodate the student teacher. For example, "teachers do not want to lose valuable teaching time and sometimes waited in front of the class impatiently". This, however, does not apply only to student teachers from ODL institutions, but also to student teachers from residential institutions.

\subsection{Theme 3: The development of a shared teaching repertoire by student teachers in an ODL environment}

Student teachers were requested to comment on whether the ODL model provided sufficient training to prepare them for the teaching profession. 


\subsubsection{Positive aspects}

Integrating reflective thinking is an experiential learning process involving decision making in a social-political context, identifying problems and searching for satisfactory answers (Taggart \& Wilson 1998). Therefore, the fundamental goal should be the ability to perform relevant teaching tasks in a variety of effective ways in a school situation. The student teacher also needs guidance in interpreting and in making explicit the integrating connections between the teaching activity and its effects. This will assist the student teachers to become legitimate peripheral participants in their school communities.

The following responses attest to this shared repertoire between the ODL study material and the teaching experiences in schools. "Yes, workbooks are clear and together with mentor teacher able to do the job." "ABSOLUTELY! ... student teachers have the chance to get into school on a learnership and experience the teaching profession from their first year." "Yes, because when I observe the mentor teacher teaching and the way they plan their lessons, is the same as the way we are taught at UNISA." "Yes. Even the principal at the school said he prefers student teachers from Unisa over any other institution." thereby the mentor teachers assists the student teachers to integrate their theoretical knowledge into practical teaching activities.

The student teacher participants commented favourably by saying that they will encourage students to study through ODL. "I would recommend students to study at Unisa ... because it is the best university." "Yes, during these four practices we experience different mentors, principals, learners and learned different styles of teaching, giving us the relevant training we need to be sufficient teachers [sic]. The student teachers commented positively on the study material provided for their BEd as well as the workbooks for the TP modules. The workbooks explain what is needed in every subject and provides lesson plans to be presented and completed in the school.

\subsubsection{Negative aspects}

Negative comments include that the student teachers "need more assistance from the ODL institution". Another student teacher referred to a "bad experience with communication and arrogant lecturers and mistakes in the study material". One student said "not at all", but did not explain why.

The negative comments pertain mostly to administrative aspects such as the waiting time for the placements to be completed, problems with study material that is not received in time and supervisors who do not respond promptly or professionally to student teachers' short messaging. It is too costly to print their study material if it is not sent in time. Some students do not have access to the internet to download the necessary material. Communication with lecturers and the TP office is difficult.

From the responses it is clear that the good experiences far outweigh the bad experiences. The ODL institution can respond favourably to all the negative aspects revealed by the research, namely that the administrative glitches should be addressed by the support systems and that placement processes should be revised. Mentor teachers and supervisors need training in order to clarify their respective roles and promote professionalism.

On a personal note, student teachers may have a problem to manage their time properly at an ODL institution as well as to fit in their teaching practice with their own working schedule.

\section{Implications and Recommendations for Teaching Practice at an Odl Institution}

A number of aspects should be addressed by the institution that may contribute positively to student teachers' experience when they conduct their teaching practice. From the findings it became clear that for better communications the ODL institution should provide a booklet on mentoring and what it entails to all schools and mentor teachers of student teachers placed at these schools. This is possible, because the TP office has a record of all placements and schools where student teachers conduct their teaching practice. Such a brochure would be helpful in spelling out what it means to be a mentor teacher, what is expected from a mentor teacher and the responsibilities of the student teacher. True partnership implies mutual respect (Hanko 1999). Mutual respect ensures the success of the joint enterprise of problem solving, collaborative approaches and mutual support, and supporting one another contributes to the empowerment of student teachers (Hanko 1999). An ODL institution relies heavily on a partnership with the schools in order to provide student teachers with guidance in the absence of lecturers. Learning from field experiences has serious limitations when conducted without opportunities for regular reflective discussions and collaboration with the lecturers or the classroom mentor teacher. Study material and workbooks should also regularly be updated in order to speak to the curricula used in schools. 
Most of the findings imply that the administration support given to student teachers in the field by the ODL institution must be improved to fill the time and place difference gap. Placement of student teachers should be streamlined in order for student teachers to be accommodated and placed at schools as early as possible in the year. There is also a definite need for better communication systems such as a call centre. This has currently been replaced by an SMS system which increases response time, because students' enquiries are dealt with only after a number of days when they only get an SMS or e-mail stating that their enquiry has been received. This often leaves student teachers frustrated. Students do not all have access to the internet and the systems are deemed to be too expensive for many teaching students.

South Africa has a shortage of qualified teachers and ODL teacher education could be a viable strategy to alleviate the shortage of graduate teachers in the country. ODL opportunities provide valuable training to under qualified in-service teachers and student teachers alike to study while being financially independent. It is an affordable way of studying and gives student teachers the opportunity to be usefully employed in order to earn money, keep up their responsibilities and become professionally qualified teachers.

\section{Conclusion}

As it is important to create a responsive teaching and learning environment, only an evaluation of the total ODL teaching and learning experience could ensure that changes made would address all the student teachers' needs. From the findings the good and the bad of the TP modules were identified by the lecturers at an ODL institution. The conclusion may be drawn that student teachers find the content of the TP modules clear and self-explanatory. However, in spite of many good points, certain bad aspects of the Teaching Practice modules need to be addressed. We can learn from the good and bad aspects identified to better understand the TP role in the training of student teachers and the subsequent need to transform certain "bad" aspects, as pointed out. The ugly would be if the bad aspects are ignored and no further research is undertaken to investigate the effect of different variables of situated experiential learning in the Teaching Practice modules at ODL institutions.

\section{Acknowledgement}

We thank Prof E. van Niekerk and Prof G. Kampfer for their profound insight as mentors.

\section{Bibliography}

Anderson, J.R., Reder, L.M., \& Simon, H.A. (1996). Situated learning and education. Educational Researcher 25(4),5-11. Available at: http://links.jstor.org/sici=0013-189x\%28199605\%2925\%3A4\%3C5\%3ASLA E\%3E2.0.co/03B2-B (as on 10/01/2007).

Bliue, A.M., Ellis, R.A., Goodyear, P., \& Hendres, D.M. (2011). Understanding student learning in context: relationships between university students' social identity, approaches to learning, and academic performance. Europa Journal Psychology Education. Available at: http://EuroPshycoEduDOI10.1007/s10212-011-0065-6 (as on 05/07/2011).

Booysen, V. (2013). Kry die meeste uit mentorskap. Rapport Loopbane, 20 October,1.

Butcher, N., Latchem, C., Manoyo, M., \& Levey, L. (2011). Distance education for empowerment and development in Africa. Distance Education 32(2),149-158. Available at: http://dx.doi.org/10-1080/01587919.2011.584844 (as on 17/04/2013).

Çakiroğlu, Ũ. (2014). Evaluating students' perspectives about virtual classrooms with regard to seven principles of good practice. South African Journal of Education 34(2), art.\#869, 9 pages, http://www.sajournalofeducation.co.za.

Clark, G., Steele, R., Niemiec, R.P., \& Walberg, J.H. (1992). Promoting teacher behaviors that promote student learning. Performance \& Instruction 31(4): 22-24.

Eacute, J., \& Esteve, M. (2000). The transformation of the teacher's role at the end of the twentieth century: new challenges for the future. Educational Review 52(2), 197-207. Available at: http://dx.doi.org10.1080/713664040. (as on 22/11/2012).

Evans, H.L. (1986). How do early field experiences influence the student teacher? Journal of Education for Teaching 12(1), 35-46.

Gokhale, A.A. (1995). Collaboration learning enhances critical thinking. Journal of Technology Education 7(1), 1-7. Available at: http://scholar.lib.vt.edu/ejournals/JTE/v7n1/gokhale.jte-v7n1.html (as on 03/10/2013).

Hanko, G. (1999). Increasing competence through collaborative problem-solving. Using insight into social and emotional factors in children's learning. London: David Fulton.

Henning E. Van Rensburg W. \& Smit B. (2004). Finding your way in qualitative research. Pretoria: Van Schaik.

Jarvis, P. (2009). Teaching whole people through Distance Education. ODL Occasional Lecture Series. Pretoria: Institute for Open and Distance Learning, Unisa.

Jedege, O. (2009). From convocation to flexible learning: the role of ODL in community development. ODL Occasional Lecture Series. Pretoria: Institute for Open and Distance Learning, Unisa. 
Juwah C. (2010). The impact of technology on distance education: implications for developing countries. 5th Lecture in the ODL Occasional Lecture Series. Pretoria: Institute for Open and Distance Learning, Unisa.

Kolb, D.A. (1984). Experiential learning. Experiences of the source of learning and development. USA: PTR Prentice Hall.

Kolb, D.A. (2013). Experiential learning (Kolb) learning theories: 1-4. Available at: http://www.learning-theories-kolb.html (as on 03/102013).

Lasley, T.J., \& Applegate, J.H. (1985). Problems of early field experience student of teaching. Teaching 7 Teacher Education 1(3), 221227.

Lave, J., \& Wenger, E. (1991). Situated learning - legitimate peripheral participation. New York: Cambridge University Press.

Lave, J., \& Wenger, E. (2011). Communities of practice. infed: 1-9. Available at: http://www.infed.org/biblio/communities_of_practice.htm (as on 15/03/2011).

Louw W.P., \& Steyn, L. (2012). Bridge over troubled water: E-portfolios: mapping the journey to meaningful workplace learning. Progressio 34(2), 140-153.

Maeroff, G.I. (1988). The empowerment of teachers: overcoming the crises of confidence. New York: Teachers College, Columbia University.

Menlo, A., \& Poppleton, P. (1990). A five country study of the work perceptions of secondary school teachers in England, the United States, Japan, Singapore and West Germany (1986-88). Comparative Education 26(2/3),173-183.

Naidu, S. (2010). Unpacking the affordances of technology for e-learning. Third Lecture in the ODL Occasional Lecture Series. Pretoria: Institute for Open and Distance Learning, Unisa.

ODL Communiqué 23. (2010). Pretoria: Unisa.

Platsidon, M., \& Metallidou, P. (2009). Validity and reliability issues of two learning style inventories in a Greek sample: Kolb's learning style inventory and Felder and Soloman's index of learning styles. International Journal of Teaching and Learning in Higher Education 20(3), 324-335.

Schlebusch, C.L. (2009). An investigation into possible obstacles with the introduction of computer applications technology in the further education and training phase in the Lejweleputswa education district. In compliance with Med in the Faculty of Management Sciences, School of Teacher Education. Welkom: Central University of Technology, Free State.

Shulman, L.S. (2004). The wisdom of practice. Essays on teaching, learning and learning to teach. USA: Jossey-Bass.

Subotzky, G., \& Prinsloo, P. (2011). Turning the tide: a socio-critical model and framework for improving the student success in open distance learning at the University of South Africa. Distance Education 32(2), 177-193. Available at: http://www.tandfonline.com/ doi/full/10.1080/01587919.2011.584846 (as on 17/04/2013).

Sykes, G., Bird, T., \& Kennedy, M. (2010). Teacher education: its problems and some prospects. Journal of Teacher Education 6(5), 464-476. Available at: http://jtesagepub_com (as on 16/02/2012).

Taggart, G.L., \& Wilson, A.P. (1998). Promoting reflective thinking in teachers. 44 action strategies. USA: Corwin Press.

Wenger, E. (1998). Communities of practice: learning, meaning, and identity. New York: Cambridge University Press.

Wenger, E. (2000). Communities of practice and social learning system. SAGE Social Science Collection 7(2), 225-246.

Unisa. (2012). Procedural manual on experiential learning. Available at: myUnisa (as on 15/02/2012).

Zeichner, K.M. (1986). Content and contexts: neglected elements in studies of student teaching as an occasion for learning to teach. Journal of Education for Teaching 12(1), 5-24. 